\title{
Effects of deforestation and forest modification on understorey birds in Central Sulawesi, Indonesia
}

\author{
M. WALTERT, A. MARDIASTUTI and MICHAEL MÜHLENBERG
}

\section{Summary}

To estimate the potential of forest birds to persist in the increasingly deforested island of Sulawesi, we undertook a mist-net survey in the understorey of natural as well as modified forest (forest garden and heavily logged forest) at submontane elevations in Central Sulawesi. A total of forty $102 \mathrm{~m}$ mist-net lines were distributed over five 16 ha study sites. Two of the sites were situated in an extensively forested valley, and three in a valley with severely fragmented forest. Of 23 species captured, only seven were typical understorey dwellers of submontane forest, five of which are Sulawesi region endemics. Most were found in similar numbers in natural and modified forest, but one species was significantly more common in modified forest. Of the five endemics, two species were confined to, and one species was significantly more abundant in, the extensively forested valley compared with the severely deforested valley. Our results suggest that the conservation of the remaining submontane forest is crucial to the conservation of Central Sulawesi's understorey bird diversity, but that many Sulawesi endemics might be able to survive in modified habitats.

\section{Introduction}

The island of Sulawesi is home to c. 224 resident landbird species, most of which are inhabitants of rainforest. Forty-one ( $18 \%$ ) of these are endemic to the main island and a further 56 species $(25 \%)$ are confined to Sulawesi and/or its satellite islands (Coates et al. 1997). As many as 11 endemic genera can be found, ranking Sulawesi among the most important Endemic Bird Areas of the world (Stattersfield et al. 1998) and contributing to Wallacea being a global biodiversity hotspot (Myers et al. 2000).

Logging and land conversion have caused dramatic decreases in the forest cover of Sulawesi, mainly in lowland and submontane regions and particularly in the northern, southern and eastern peninsulas (Collins et al. 1991). Sulawesi's lowland forest has virtually disappeared (FWI/GFW 2002) and forest margins are progressively shifting towards higher elevations. It is very likely that this loss of habitat (Waltert et al. 2004b), as well as increased hunting levels (e.g. O'Brien and Kinnaird 1996, 2000, Rosenbaum et al. 1998), and possibly pollution (Thiollay and Rahman 2002), have caused declines in Sulawesi's terrestrial vertebrate fauna.

In the Lore Lindu area of Central Sulawesi, forest is now mainly restricted to protected areas, but according to our own unpublished observations, illegal agricultural encroachments have created forest margins characterized by habitat mosaics of secondary forest and small-scale plantations. This has limited the availability of undisturbed forest at submontane elevations. 
Although deforestation and forest modification can be expected to pose severe threats to the bird fauna, few studies to date have attempted to assess the effect of human impact on Wallacean bird communities (but see Marsden 1998, Alvard and Winarni 1999, Thiollay and Rahman 2002). To our knowledge, there is no published quantitative study on the understorey birds in the area. Understorey insectivores are considered to be particularly sensitive to forest disturbance and fragmentation (Karr 1982, Wong 1985, Lambert 1992, Thiollay 1992, Johns 1996, 1997, Laurance et al. 2002). They can easily be sampled in a quantitative way using mist-nets (Karr 1981), which permits comparisons of data from different researchers with varying abilities and experience in detecting rainforest birds and minimizes misidentifications. Environmental stress can also be estimated using morphological measurements of the birds (Lens et al. 1999; Anciăes and Marini 2000).

The aim of this study was to describe basic patterns of understorey bird diversity from a poorly known biogeographical region and to assess the potential of understorey bird species to persist in the modified forest habitats which remain. We compared the abundance and species richness of understorey bird assemblages between two submontane valleys with different amounts of forest cover and between natural and modified (logging and small-scale agriculture) forest within the Lore Lindu National Park, Central Sulawesi. We hypothesized that understorey bird species richness and abundance will vary according to both the overall amount of remaining forest cover in the different valleys and the types of forest modification in the different habitats studied.

\section{Study area}

The Lore Lindu National Park in Central Sulawesi is approximately $2,180 \mathrm{~km}^{2}$ in size (TNC/BTNLL 2002). It ranges from c. 200 to $2,610 \mathrm{~m}$ above sea level (m.a.s.l.) and is largely mountainous with $64 \%$ of its area being located above 1,200 m.a.s.l. (Waltert et al. 2004a). Annual precipitation lies between 2,500 and 3,500 mm (Wirawan 1981, in Watling 1983). In 1999, the Park contained approximately $770 \mathrm{~km}^{2}$ of closed canopy forest at low and moderate altitudes up to 1,200 m.a.s.l. (Waltert et al. 2004a; Figure I). At that time these areas were still continuous along the northern and western Park border but were already severely fragmented along the valleys bordering the Park to the east. This study was conducted in two different valleys: the Palolo valley, which is still extensively forested and characterized by less fragmented forest at submontane elevations, and the Napu valley, where submontane forest is much more reduced in comparison with Palolo (Figure 1 ).

\section{Palolo valley}

The Palolo valley is located at the northern Park border. As in other valleys surrounding the Park, areas of the Palolo valley situated outside the National Park are largely deforested. At the time this study was conducted (2001/2002), the forest border was situated at altitudes between $c .750$ and 1,000 m.a.s.l. and was largely congruent with the Park's borders. However, the marginal zone of the forest was strongly influenced by human activities including forest gardening and collection of rattan and firewood, as well as hunting and snare-trapping. Forest gardening and planting of tree crops (coffee and cocoa) were mainly found within a distance of $500 \mathrm{~m}$ from the Park's 


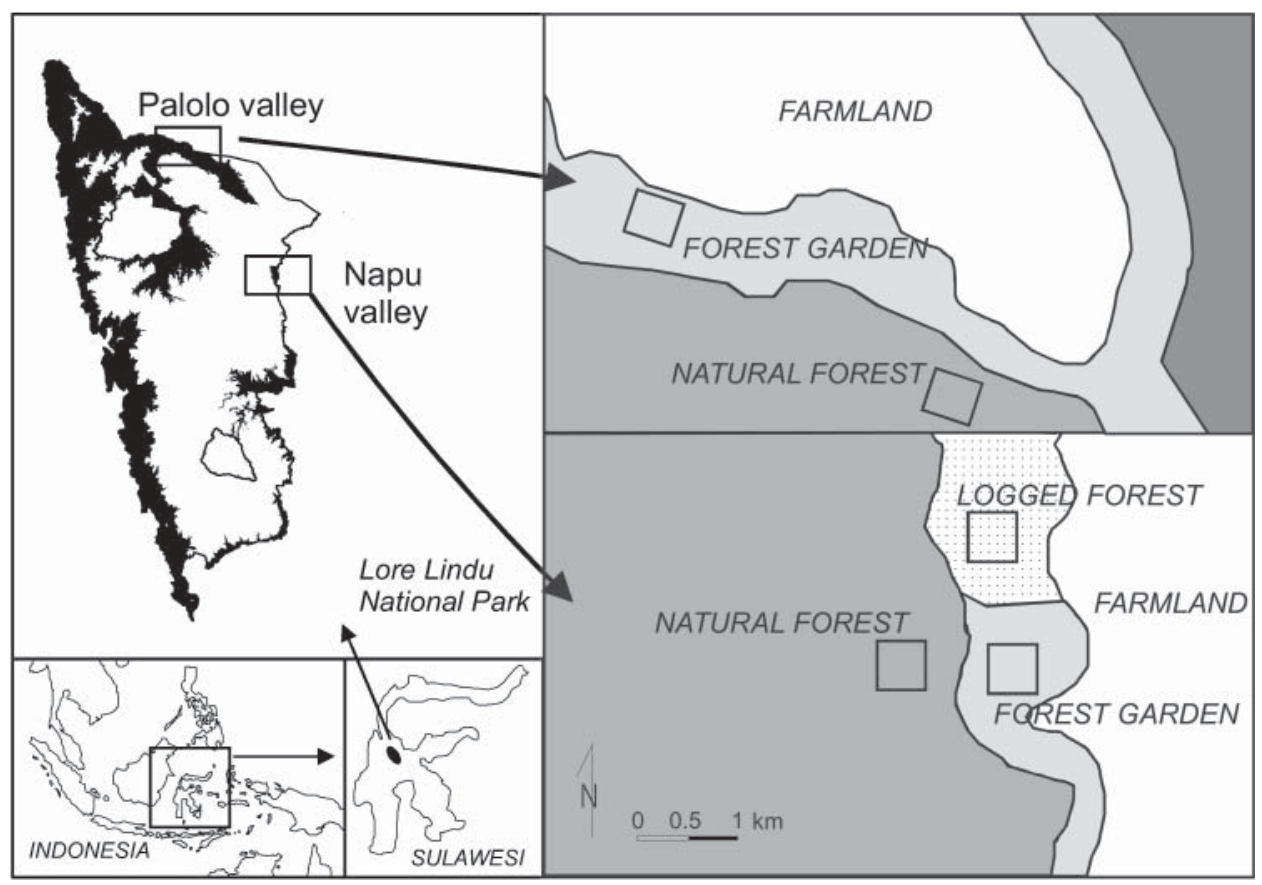

Figure 1. Location of Sulawesi within Indonesia, Lore Lindu National Park, and Park area below $1200 \mathrm{~m}$ a.s.l. (black; from Waltert et al. 2004a). The locations of the Palolo and Napu valleys and five 16 ha study sites are also shown.

boundary, and other signs of human disturbance such as rattan collection were found in more inaccessible areas above 900 m.a.s.l., at distances of more than $1 \mathrm{~km}$ from the forest edge. A study in 1994 indicated that forest near the Park border was undisturbed (Bynum 1999) and that human activities near the Park border had started only recently.

In the Palolo valley, two 16 ha study sites were selected: a forest garden and a natural forest site. The forest garden site was situated at c. 800 m.a.s.l., near Kamarora Field Station at the forest border ( $\mathrm{OI}^{\circ} 12^{\prime} \mathrm{S}, 12 \mathrm{O}^{\circ} \mathrm{O} 8^{\prime} \mathrm{E}$ ) (Figure 1 ). It included a mosaic of old small-scale subsistence farms, recently abandoned farms and regenerating secondary forest (Figure $2 \mathrm{~B}$ ). The forest structure was similar to that of the natural forest (Figure 2A) as upper and middle layers of the forest were largely intact. The understorey, however, consisted of dense thickets in abandoned areas and around active farms, but was very sparsely vegetated at active farming sites. The major crop was coffee, but bananas, chilli and other minor crops were also planted.

Because undisturbed forest was difficult to access and could only be found at higher elevations, the natural forest site selected at Palolo valley was approximately $4 \mathrm{~km}$ from the forest garden site at about 1,000 m.a.s.l., and c. $1.5 \mathrm{~km}$ from the forest border $\left(\mathrm{O}^{\circ} 13^{\prime} \mathrm{S}, 120^{\circ} \mathrm{Og}^{\prime} \mathrm{E}\right)$. In contrast to the forest garden, there were no signs of human impact (e.g. major breaks in the canopy or manually cleared understorey) (Figure 2A). A prominent sign of (near-)natural conditions was the presence of rattan Calamus spp. and other palms, including screw palms (Pandanaceae) and large epiphytes at 


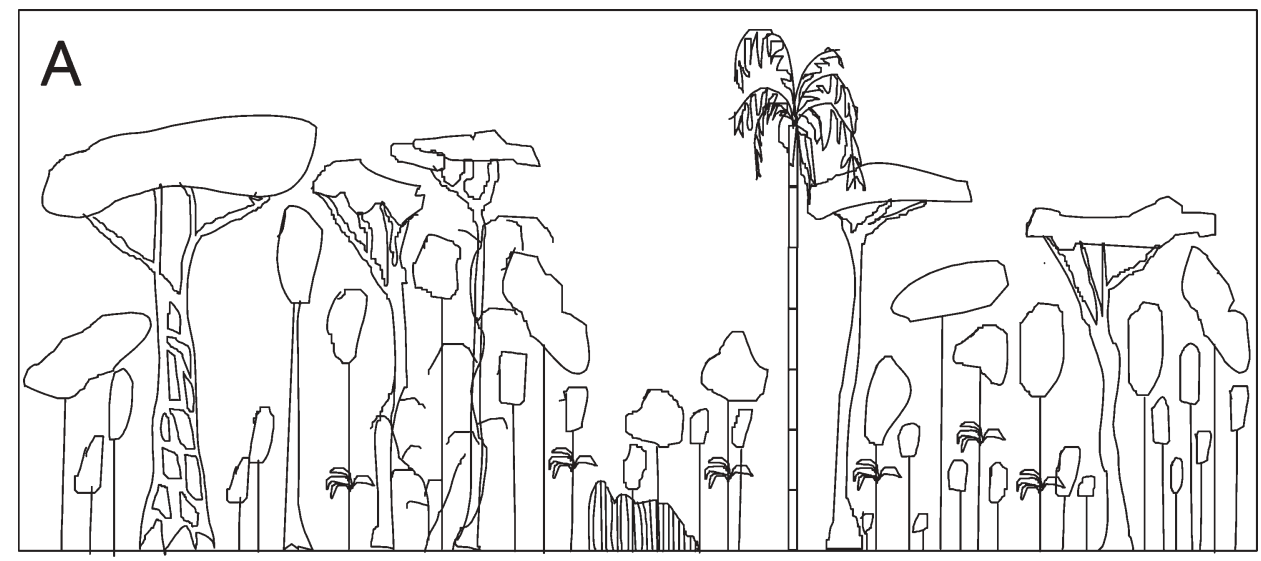

B
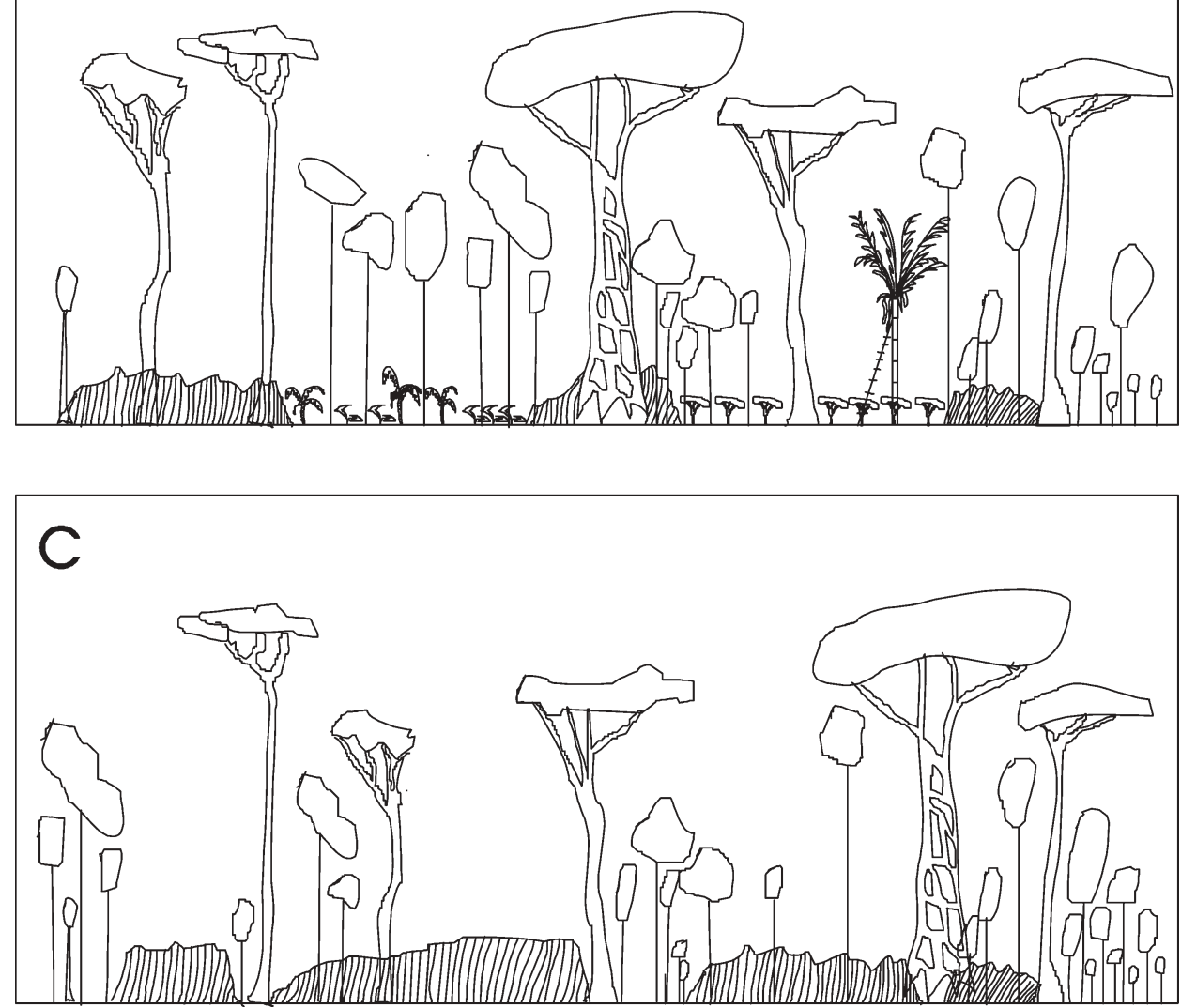

Figure 2. Vegetation profiles along a $200 \mathrm{~m}$ transect, based on sketches made in the field. (A) Natural forest; $(B)$ forest garden with cacao trees, bananas, Arenga palm; $(C)$ logged forest. Shaded areas represent the extent of thick secondary growth. 
lower understorey level. The site was, however, accessible by one or two major trails, and rattan collection as well as snare-trapping of smaller mammals were observed.

\section{Napu valley}

The Napu valley is located at the eastern border of the Park and is separated from the Palolo valley by mountain ranges reaching more than 1,700 m.a.s.l. At this valley, three 16 ha study sites were selected, one each in natural forest, forest garden and logged forest, all located at 1,050 m.a.s.l. As in the Palolo valley, the bottom of the Napu valley has been largely cleared. The Park's border in this area approaches 1,100 m.a.s.l. and submontane forest below 1,200 m.a.s.l. is now much reduced compared with Palolo, leaving only a relict patch in which our three study sites were situated (Figure 1 ).

The natural forest site was $c .500 \mathrm{~m}$ from the forest border $\left(1^{\circ} 25^{\prime} \mathrm{S}, 120^{\circ} 18^{\prime} \mathrm{E}\right)$. The site was relatively undisturbed, and no major signs of logging were visible at the time of our study. Rattan palms were small in size and scarce, but the canopy was closed. The forest garden site $\left(1^{\circ} 26^{\prime} \mathrm{S}, 120^{\circ} 18^{\prime} \mathrm{E}\right)$ was characterized by a closed canopy but the understorey was partly cleared, containing a mixture of small-scale coffee plantations and long-overgrown former plantations.

At the logged forest site $\left(1^{\circ} 24^{\prime} \mathrm{S}, 120^{\circ} 18^{\prime} \mathrm{S}\right)$ canopy closure was estimated at $c .40 \%$ (Figure $2 \mathrm{C}$ ). Timber was frequently carried out of this forest site along numerous permanent tracks with the help of buffaloes (personal observations). The extracted wood was mainly used in the construction of private homes, needed for the continuing influx of immigrants from the neighbouring Poso province. No comparable logged site could be found in the Palolo valley.

\section{Methods}

\section{Data collection}

Our research was conducted between 21 December 2000 and 21 February 2001 at Palolo and between 5 December 2001 and 18 January 2002 at Napu. Mist-netting was conducted using standard procedures described in Waltert (2000a, b). A combination of 6- and 12-m-long mist-nets, $2.7 \mathrm{~m}$ high with $16 \mathrm{~mm}$ mesh, was used to produce a single 102-m net-line for which narrow trails were cut in the understorey. Net trails were positioned on a systematic grid, using a spacing of $100 \mathrm{~m}$, with trails being parallel to each other. The net line was opened for 10 hours from 15 hoo until 18 hoo and 6 hoo until 13 hoo on the following day. The whole net line was then moved to another net trail, $100 \mathrm{~m}$ away within each 16 ha study site, resulting in a total of eight 102-m lines per study site and $40(8 \times 5$ study sites $)$ in total. The sampling effort amounted to $c$. 680 net-hours for each study site $(3,400$ net-hours in total). Net lines were checked every $1-2$ hours. Birds were identified and banded with uniquely numbered metal rings. Birds found at 18 hoo in mist-nets were kept in cotton bags until 7 hoo the next day to avoid possible disorientation of animals released in the dark.

\section{Data analysis}

For each study site, we counted the total number of species detected, the number of species represented by only a single individual (singletons), as well as Fisher's alpha, 
Simpson, Shannon-Weiner diversity and Shannon-Weiner Evenness indices (see Magurran 1988). In most field studies, not all species which are actually present are also recorded (see Nichols and Conroy 1996). Therefore, we also quantified 'estimated' species richness that takes into account the fact there are species which are not actually recorded but whose presence can be inferred from the pattern of observed species occurrence. To calculate estimated species richness, we used the estimator ACE, a non-parametric species richness estimator based on abundance data (Chao et al. 1993), as well as the Michaelis-Menten species richness estimator MME, which fits an asymptotic function to the sample-based rarefaction curve (Colwell et al. 2004). To calculate measures of ecological diversity for each site and to extrapolate species richness from samples, Colwell's (1997) software EstimateS version 5.O.I was used.

We also used multidimensional scaling based on the Sörensen quantitative sample similarity index (Magurran 1988) to depict dissimilarities in species composition among the five sites. To analyse differences in mean abundance per sample (net line) between forest habitats and valleys we used a two-way ANOVA. Tukey's honestsignificant-difference test (HSD test) was used for multiple comparisons of means. Only species with a minimum of nine captured individuals were tested. Only one individual was recaptured in a different net line and was excluded from the analysis to avoid pseudo-replication. All statistical analyses were performed using Statistica 5.I (Statsoft 1995).

\section{Results}

Numbers of individuals and species; species composition

On average, 50.8 ( $\left.\pm_{17.1} \mathrm{SD}\right)$ individuals were trapped in the plots. The mean number of species per plot amounted to $9.8( \pm 2.8 \mathrm{SD})$ and the total numbers of species in all five plots combined was 23 (254 individuals).

Using the single $102 \mathrm{~m}$ mist-net lines as a sampling unit, mean numbers of individuals were higher in the extensively forested Palolo valley than in the more deforested Napu valley (ANOVA, $F_{1,35}=9.70, P=0.004$; Figure $3 \mathrm{~h}$ ). Differences were especially pronounced between Palolo forest gardens (10.0 \pm 3.1 individuals per $102 \mathrm{~m}$ net-line) and Napu natural forest ( $4.75 \pm 1.8$; Tukey's HSD test, $P=0.015)$ or Napu logged forest (5.I \pm 2.6 ; Tukey's HSD test, $P=0.029$ ). Mist-netting in the Palolo forest garden site also produced the highest number of species, but similarly high or higher diversity indices (Fisher's $\alpha$-diversity, Simpson index and Evenness) as well as species richness estimators (ACE, MMMean) were obtained in Napu natural forest (Table I).

There was a major difference between the species composition of the two valleys. Comparing species composition between sites within valleys, the sites at Napu were very similar, while the two Palolo sites were rather more different from each other (Figure 4).

Only seven of the 23 species present in our samples are classified as understorey dwellers for which submontane forests represents an important part of their altitudinal range (see Appendix). These same species were the most common ones: in the extensively forested Palolo valley, the understorey bird community was composed of four sallying insectivores: the Mangrove Blue Flycatcher Cyornis rufigastra, the Rufous-throated Flycatcher Ficedula rufigula, the Rusty-bellied Fantail Rhipidura 


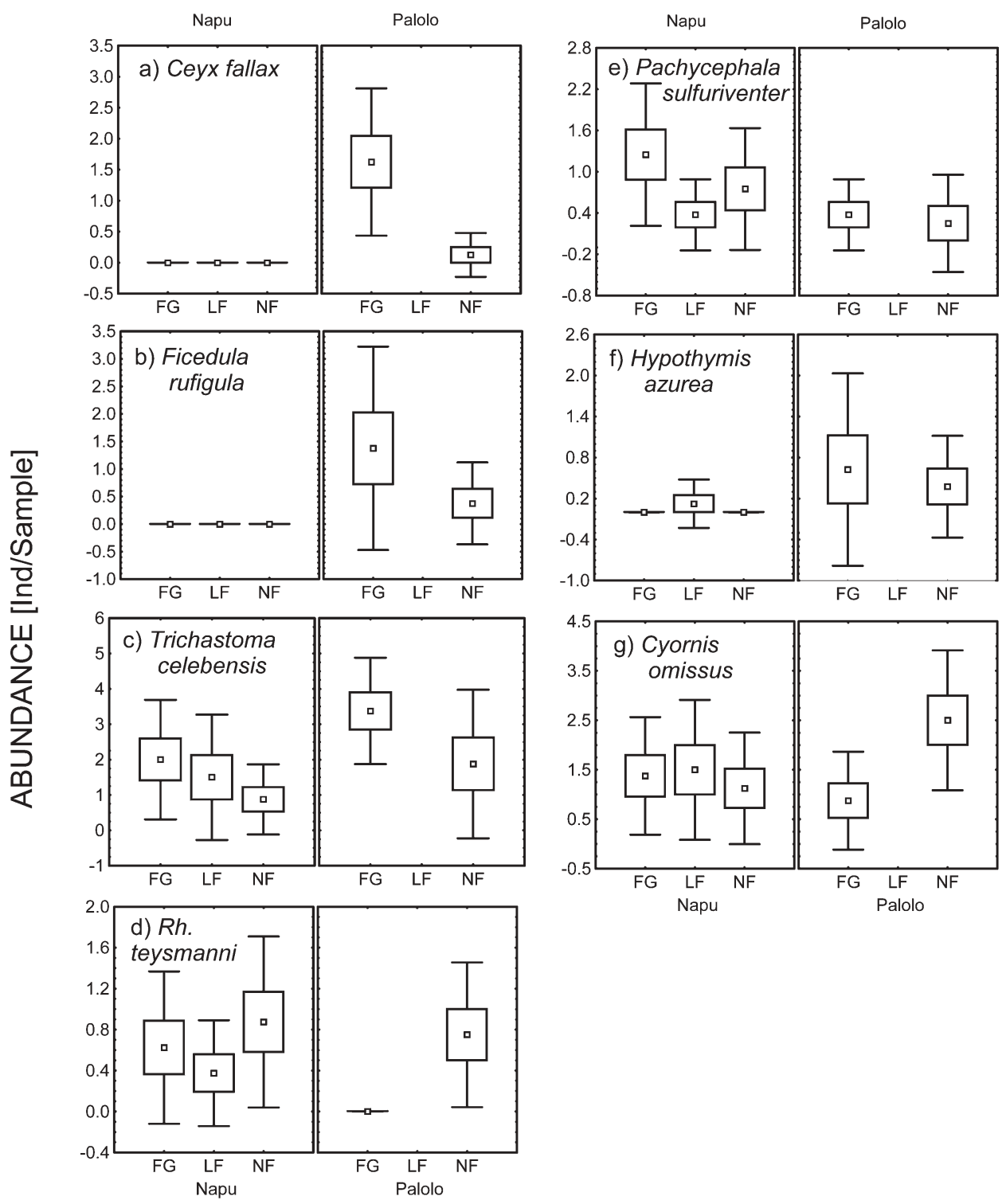

\section{STUDY SITE}

Figure 3. Mean, standard error and standard deviation for numbers of individuals trapped in $102 \mathrm{~m}$ mist-net lines set for 10 daylight hours in three forest habitats (NF, natural forest; FG, forest garden; LF, logged forest) of two submontane valleys (Palolo, Napu) differing in their degree of forest fragmentation (fragmented, continuous), at Lore Lindu National Park, Sulawesi.

teysmanni and the Black-naped Monarch Hypothymis azurea. The Sulawesi Babbler Trichastoma celebense, the Yellow-bellied Whistler Pachycephala sulfuriventer and the Sulawesi Dwarf Kingfisher Ceyx fallax were also frequently trapped. These species accounted for $89 \%$ of all individuals trapped in Palolo valley and all but two, 
Table 1. Number of individuals, species, diversity indices ${ }^{\mathrm{a}}$ and species richness estimators ${ }^{\mathrm{b}}$ of understorey bird communities at five sites in submontane areas of Lore Lindu National Park, Central Sulawesi.

\begin{tabular}{|c|c|c|c|c|c|c|}
\hline & & \multicolumn{2}{|l|}{ Palolo valley } & \multicolumn{3}{|l|}{ Napu } \\
\hline & & $\begin{array}{l}\text { Natural } \\
\text { forest }\end{array}$ & $\begin{array}{l}\text { Forest } \\
\text { garden }\end{array}$ & $\begin{array}{l}\text { Natural } \\
\text { forest }\end{array}$ & $\begin{array}{l}\text { Forest } \\
\text { garden }\end{array}$ & $\begin{array}{l}\text { Logged } \\
\text { forest }\end{array}$ \\
\hline Individuals & & 51 & 80 & 38 & 45 & 40 \\
\hline Species & & 8 & 14 & 11 & 7 & 9 \\
\hline Singletons & & 2 & 3 & 5 & 3 & 3 \\
\hline Diversity & Fisher's $\alpha$ (SD) & $2.66(0.63)$ & $4.91(0.91)$ & $5.19(1.33)$ & $2.32(0.58)$ & $3.61(0.92)$ \\
\hline Diversity & Simpson ( $1 / D)$ & 4.02 & 6.02 & $7 \cdot 40$ & $4 \cdot 30$ & 5.57 \\
\hline Diversity & $H_{\mathrm{S}}$ & 1.59 & 2.1 & 1.99 & 1.54 & 1.75 \\
\hline Evenness & $H_{\mathrm{S}} / \ln S$ & 0.80 & 0.77 & 0.83 & 0.79 & 0.79 \\
\hline Estimator & $\mathrm{ACE}$ & $9 \cdot 44$ & 16.07 & 16.76 & 12.16 & 11.18 \\
\hline Estimator & MMMean & 10.6 & 18.89 & 16.62 & 7.82 & 11.81 \\
\hline
\end{tabular}

aDiversity (Fisher's $\alpha$, Shannon $H_{\mathrm{s}}$, Simpson) after Magurran (1988).

${ }^{b}$ Species richness estimators (ACE, MMMean) after Colwell (1997).

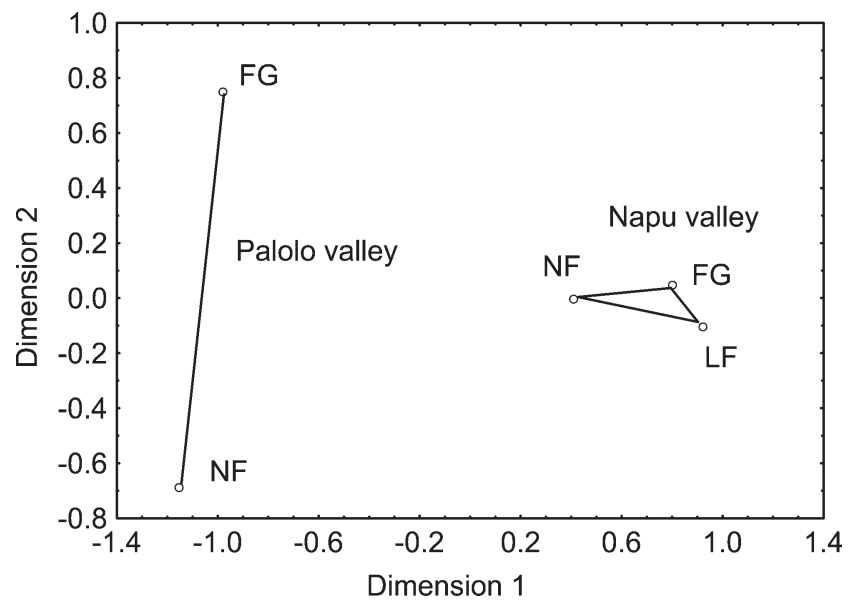

Figure 4. Multidimensional scaling of bird communities mist-netted in five study sites (NF, natural forest; FG, forest garden; LF, logged forest) and two valleys (Palolo, Napu) of Lore Lindu National Park, Sulawesi. Based on dissimilarities from the Sörensen quantitative sample similarity index (Magurran 1988).

the Black-naped Monarch and the Mangrove Blue Flycatcher, are endemic to the Sulawesi biogeographical region (White and Bruce 1986, Coates et al., 1997).

In the more deforested Napu valley, the understorey bird community was dominated by fewer species than Palolo, consisting mainly of four species which were also netted at Palolo (Mangrove Blue Flycatcher, Rusty-bellied Fantail, Sulawesi Babbler and Yellow-bellied Whistler). These four species accounted for $81 \%$ of all individuals trapped. Two species found in Palolo (Sulawesi Dwarf Kingfisher and Rufous-throated Flycatcher) were not recorded in Napu valley.

The remaining species netted were mainly representatives of the lower midstoreycanopy (i.e. flowerpeckers Dicaeidae, sunbirds Nectariniidae, Australian robins 
Petroicidae, honey-eaters Meliphagidae, white-eyes Zosteropidae, and the island verditer flycatcher Eumyias panayensis), larger non-passerine species (i.e. hawks Accipitridae, cuckoos Cuculidae, pigeons Columbidae) or species that have their main distribution at higher altitudes than our study sites (i.e. Chestnut-backed Bush Warbler Bradypterus castaneus, Snowy-browed Flycatcher Ficedula hyperythra) (see Coates et al. 1997; Appendix).

\section{Differences in abundance between valleys and habitats}

For the seven commonest species (see above), the mean number of individuals trapped per $102 \mathrm{~m}$ mist-net line is shown in Figure 3. Comparisons of abundance data revealed significant differences between the two valleys (Palolo, Napu) in three species and between habitats in one species (Table 2). The Sulawesi Dwarf Kingfisher (Figure 3a: Tukey's HSD test, $P<0.001$ ), the Rufous-throated Flycatcher (Figure 3b; Tukey's HSD test, $P<0.005$ ) and the Sulawesi Babbler (Figure 3c; Tukey's HSD test, $P<0.045$ ) were all significantly more abundant in the extensively forested Palolo than in the more deforested Napu valley (Table 2). Although caught more frequently in Palolo, there was no significant difference in abundance of the Black-naped Monarch between the valleys (Fig. 4f; Tukey's HSD test, $P<0.060$ ). None of the species was more abundant in Napu than Palolo, although one species, the Yellow-bellied Whistler, was nearly so (Figure 3e; Tukey's HSD test, $P<0.06$ ).

The Sulawesi Dwarf Kingfisher was more frequent in forest garden than in natural forest (Figure 3a; Tukey's HSD test, $P<$ o.001). However, while the Sulawesi Babbler was more common in forest gardens than natural forest, and the Rusty-bellied Fantail appeared to be more common in natural forest than forest garden, these differences were not significant (Figure 3c; Tukey's HSD test, $P<0.078$; Figure $3 \mathrm{~d}$; Tukey's HSD test, $P<0.081$ ).

Table 2. Effects of upland valley sampled (two valleys: Palolo, Napu) and habitat (natural forest, forest garden and logged forest) on numbers of bird individuals trapped in $102 \mathrm{~m}$ mist-net samples

\begin{tabular}{|c|c|c|c|c|c|}
\hline Species & & Factor & $F_{1,35} / F_{2,35}$ & $P<$ & Highest abundance \\
\hline \multirow[t]{2}{*}{ Ceyx fallax } & \multirow[t]{2}{*}{ Sulawesi Dwarf Kingfisher } & Valley & 23.93 & 0.001 & \multirow{4}{*}{$\begin{array}{l}\text { Palolo } \\
\text { Forest garden }\end{array}$} \\
\hline & & Habitat & $9 \cdot 32$ & 0.001 & \\
\hline \multirow[t]{2}{*}{ Cyornis rufigastra } & \multirow[t]{2}{*}{ Mangrove Blue Flycatcher } & Valley & 0.79 & 0.382 & \\
\hline & & Habitat & 1.24 & 0.303 & \\
\hline \multirow[t]{2}{*}{ Ficedula rufigula } & \multirow[t]{2}{*}{ Rufous-throated Flycatcher } & Valley & 9.27 & 0.005 & \multirow[t]{8}{*}{ Palolo } \\
\hline & & Habitat & 2.03 & 0.146 & \\
\hline \multirow[t]{2}{*}{ Hypothymis azurea } & \multirow[t]{2}{*}{ Black-naped Monarch } & Valley & 3.79 & 0.060 & \\
\hline & & Habitat & 0.21 & 0.811 & \\
\hline \multirow[t]{2}{*}{ Pachycephala sulfuriventer } & \multirow[t]{2}{*}{ Yellow-bellied Whistler } & Valley & 3.81 & 0.059 & \\
\hline & & Habitat & 1.11 & 0.340 & \\
\hline \multirow[t]{2}{*}{ Rhipidura teysmanni } & \multirow[t]{2}{*}{ Rusty-bellied Fantail } & Valley & 1.49 & 0.231 & \\
\hline & & Habitat & 2.76 & 0.078 & \\
\hline \multirow[t]{2}{*}{ Trichastoma celebense } & \multirow[t]{2}{*}{ Sulawesi Babbler } & Valley & 4.78 & 0.036 & \multirow[t]{2}{*}{ Palolo } \\
\hline & & Habitat & 2.85 & 0.072 & \\
\hline
\end{tabular}

Analysis is based on two-way analysis of variance; number of mist-net samples $n=40$. Significant results are highlighted in bold.

aTukey's HSD test, $P<0.05$. 


\section{Discussion}

Understorey bird species richness compared with areas west of Wallace's line

There are few quantitative studies on Wallacean bird communities despite their global importance for biodiversity conservation (but see Alvard and Winarni 1999, Marsden 1998). Sulawesi's avian endemism is remarkably high but its species richness (224 landbird species) is relatively low compared with the smaller island of Java which has 340 resident bird species (MacKinnon et al. 1997). The low diversity of understorey bird species that we found within habitats is a reflection of this general biogeographical pattern, but the disparity seems to be especially pronounced for insectivorous understorey species. In comparable studies on the lowlands of Borneo and peninsular Malaysia, the number of insectivorous understorey passerines can be up to 3 times greater (e.g. Wong 1985, Lambert 1992). This higher species richness west of Wallace's line is due to a higher number of sallying species (Muscicapidae, Monarchidae), gleaners (e.g. Timaliidae) as well as species from guilds which are not represented at all in Central Sulawesi, such as the insectivorous-frugivorous Pycnonotidae (Lambert 1992). It is unlikely that the low species number in our study reflects insufficient sampling effort, as only two additional passerine understorey species are known to occur at respective elevations in the Park (Red-backed Thrush Zoothera erythronota and Red-bellied Pitta Pitta erythrogaster; see Coates et al. 1997, Merker and Ebert in press.).

\section{Shifts in vertical stratification}

We found a relatively high species richness and diversity in the forest garden habitats of the Palolo valley. Higher species richness in disturbed than natural tropical forest habitats has been reported for birds and butterflies (Andrade and Rubio-Torgler 1994, Bennett and Dahaban 1995, Karim-Dakog et al. 1997, Alvard and Winarni 1999, Hill et al. 1995, Brown 1997, Wood and Gillman 1998, Fermon et al. 2000), but is often due to a local increase in edge species, e.g. in smaller nectarivores or frugivores (Murphy 1989, Thiollay 1995, Mason 1996, Dale et al., 1999). In canopy gaps and disturbed forest, bird species shift their vertical range downwards (Terborgh and Diamond 1970, Pearson 1971, Greenberg 1981, Bell 1982, Levey 1988, Driscoll and Kikkawa 1989) as do butterflies (DeVries 1987, Wood and Gillman 1998, Fermon et al. 2005). Our experience confirms that understorey data from disturbed sites might be strongly biased by an increased proportion of higher-strata species. We caught several species which are typical canopy-dwellers of undisturbed forest, in particular flowerpeckers, sunbirds and white-eyes (Driscoll and Kikkawa 1989, Coates et al. 1997), in the understorey of one forest garden. If these species are excluded from the analysis, overall species richness and number of individuals per site are more similar between forest garden and natural forest habitats.

\section{Differences in abundance between natural and modified forest}

Our data do not show any negative impact of forest modification on the abundance of the understorey bird species studied. The Sulawesi Dwarf Kingfisher was even more abundant in the forest garden than the natural forest habitat. From our data, we can conclude that the studied species are capable of colonizing modified forests. Our 
results are corroborated by studies on bird diversity in different land-use systems, showing that secondary forest areas along the borders of Lore Lindu are used by many species (Schulze et al. 2004; Waltert et al. 2004b). It remains unclear, however, to what extent these secondary forests represent suitable habitats for the long-term persistence of these species. Predation on artificial nests has been found to be higher in disturbed tropical forest than in natural forest in South-east Asia (Cooper and Francis 1998, Wong et al. 1998) as well as in our own study sites in Sulawesi (PangauAdam 2003). The possibility of higher predation pressure in disturbed forest may have relevance for the species in this study. In addition, remote sensing analyses reveal that much of the forest in the Palolo and Napu valley was cleared between 1983 and 1999 (TNC/BTNLL 2002). It is therefore possible that densities of birds in remaining forest habitats might not yet be in equilibrium and that many individuals are "trapped" in suboptimal conditions. Longer-term monitoring would be necessary to substantiate these hypotheses.

\section{Differences in species composition between valleys}

Of the 23 netted bird species, seven species are typical for submontane elevations in Central Sulawesi and for three of these, deforestation has been shown to have a significantly negative impact on their abundance. Two of these species, Sulawesi Dwarf Kingfisher and Rufous-throated Flycatcher, both endemics, have a known altitudinal range below 1200 m.a.s.l. (Coates et al. 1997) and were completely absent from the largely deforested Napu valley. It is unknown whether these species have ever occurred in this valley; however, the Napu/Besoa valley system bordering the Lore Lindu National Park to the East, is extensive, and - at least in pre-colonial times - was covered by extensive submontane rainforest. It is therefore very likely that this area now contains only a fraction of the bird species found in valleys where forest cover is greater, less fragmented and adjacent to lower-lying areas. Similar patterns of species loss have also been reported for tree communities in submontane forests of Napu compared with Palolo (Kessler et al. 2005, P. J. A. Kessler, pers. comm.).

\section{Conservation}

The bird fauna of lowland and hill forest habitats in Central Sulawesi is currently under serious pressure due to rapidly increasing deforestation and other forms of human disturbance. If the Sulawesi upland form of the Mangrove Blue Flycatcher (Cyornis rufigastra) is upgraded to species level (Sulawesi Blue Flycatcher Cyornis omissus; see Monroe and Sibley 1993), there are 25 restricted-range species of the Sulawesi region which are mainly confined to lowland/hill forest habitats (Stattersfield et al. 1998). Six of these are understorey species present in the Lore Lindu National Park (Watling 1983, Coates et al. 1997).

In the Palolo valley, three of these species were recorded: the Sulawesi Dwarf Kingfisher, the Mangrove Blue Flycatcher and the Rufous-throated Flycatcher. In the less forested Napu valley, only the Mangrove Blue Flycatcher was found, the Rufousthroated Flycatcher being replaced by its mountain congener, the Snowy-browed Flycatcher. The absence of three other Sulawesi endemics (Lilac-cheeked Cittura cyanotis and Green-backed Kingfisher Actenoides monachus, as well as the abovementioned Red-backed Thrush) in our mist-net samples could indicate that they need 


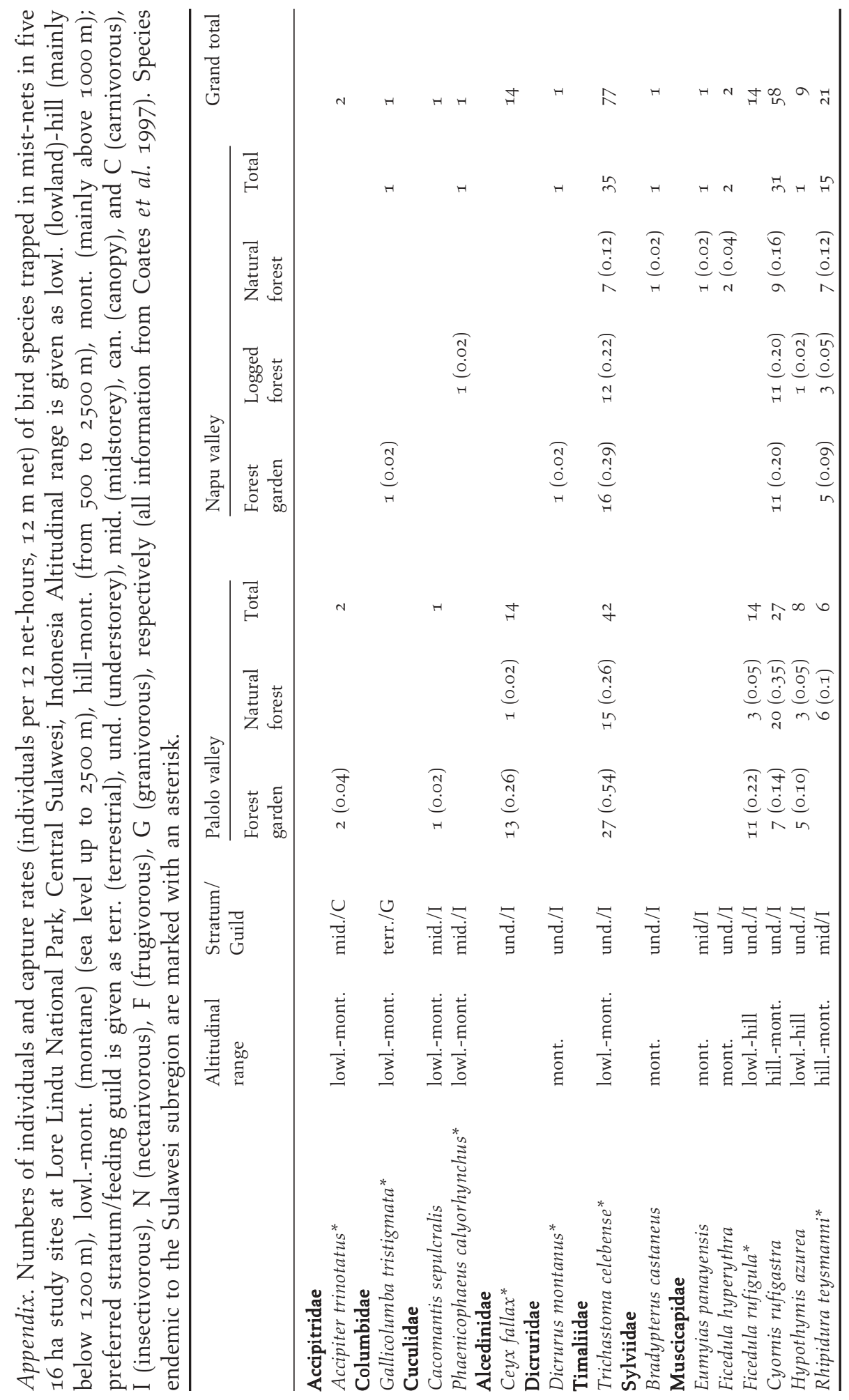




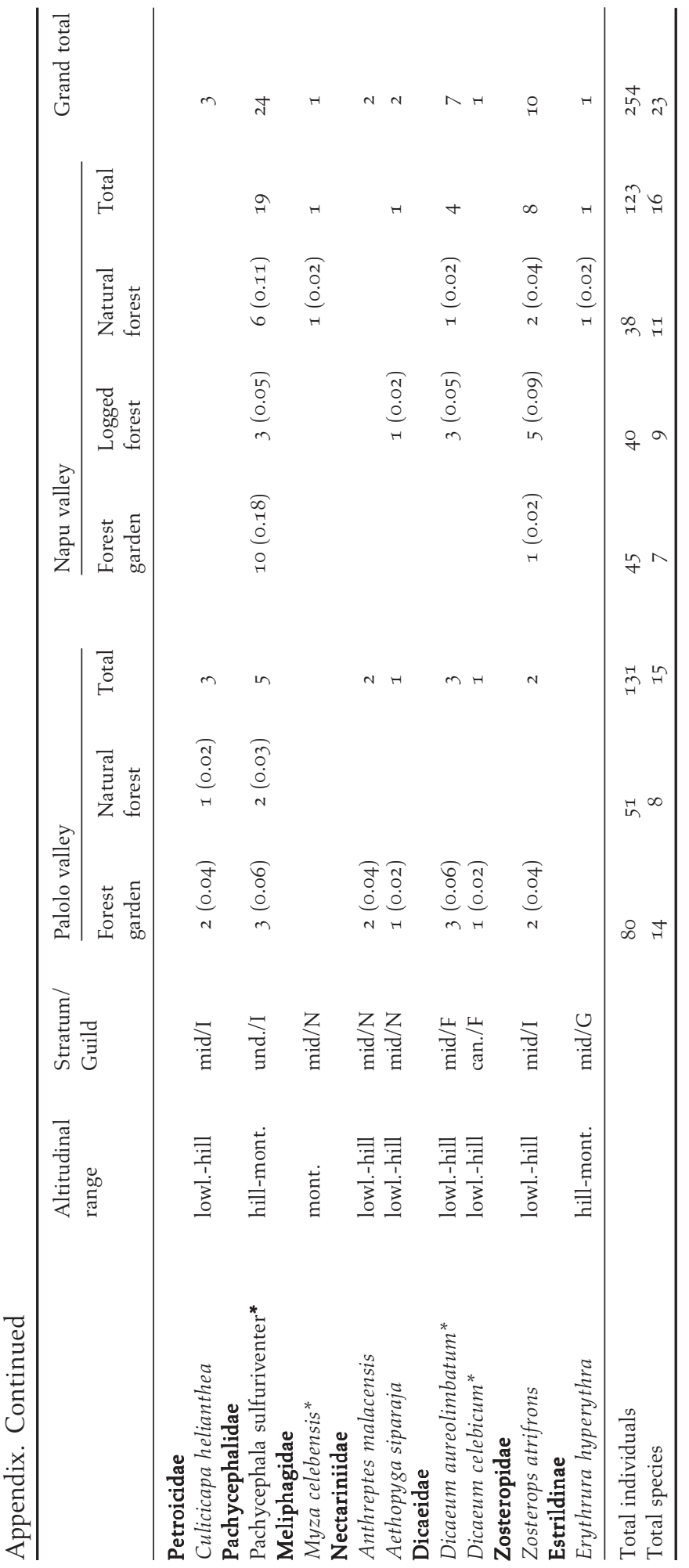


more extensive lowland habitat below 1,000 m.a.s.l. (Watling 1983, Coates et al. 1997, Stattersfield et al. 1998) and that they now occur in very low densities in the region. It seems obvious that a further decrease of the remaining lowland/hill forest around the Lore Lindu National Park threatens all lowland/hill forest species by reducing their habitat to fragments surrounded by either montane forest or farmland. Sixtytwo $(47 \%)$ of the 131 resident forest species of the Lore Lindu National Park are confined to areas below 1,200 m.a.s.l. (data from Coates et al. 1997, Nur Mallo and Ma'dika 1999, Waltert et al. 2004a). Illegal encroachments and organized timber exploitation have seriously increased since 1999 (Waltert et al. 2004a). It has been estimated that closed lowland and hill forest (below 1200 m.a.s.l.) within the Park has been reduced by nearly 19\% between 1999 and 2001, most of it in the north-eastern part of the Park including the Palolo valley (Waltert et al. 2004a). This recent loss of forest habitat in the Park's hill forest zone is serious since most of the Park's area is located above 1,200 m.a.s.l. If measures are not taken immediately to stop further illegal encroachments, the Park could lose its remaining lowlands and with them up to half of its forest birds.

\section{Acknowledgements}

This study was part of the collaborative research between Georg-August University of Göttingen, University of Kassel, Bogor Agricultural University and Tadulako University Palu, entitled 'Stability of Rainforest Margin Areas in Indonesia (STORMA)'. STORMA is financed by the German Research Council (DFG). We are grateful for the permission to conduct fieldwork to Pak Banjar (Balai Taman Nasional Lore Lindu, Palu). The authors especially acknowledge the work of the co-ordinating teams in Göttingen, Bogor and Palu, and of Drs Elijohnnadi (Palu), Maike Langkau and Stefan Merker (Göttingen) as well as Pak Agus, Pak Thony, Pak Sapri and Pak Punggu (Kamarora). Special thanks go to Heleen Fermon for assistance in data analysis, Richard Noske for manuscript corrections, as well as the editor and an anonymous reviewer for their help.

\section{References}

Alvard, M. S. and Winarni, N. L. (1999) Avian biodiversity in Morowali Nature Reserve, Central Sulawesi, Indonesia and the impact of human subsistence activities. Trop. Biodiv. 6: 59-74.

Anciăes, M. and Marini, M. A. (2000) The effects of fragmentation on fluctuating asymmetry in passerine birds of Brazilian tropical forests. J. Appl. Ecol. 37: 1013-1028.

Andrade, G. I. and Rubio-Torgler, H. (1994) Sustainable use of the tropical rainforest: evidence from the avifauna in a shifting cultivation habitat mosaic in the Colombian Amazon. Conserv. Biol. 8: 545-554.

Bell, H. L. (1982) A bird community of lowland rainforest in New Guinea. 4. Birds of secondary vegetation. Emu 82: 217-224.

Bennett E. L. and Dahaban, Z. (1995) Wildlife responses to disturbances in Sarawak and their implications for forest management. Pp. 66-86 in R. B. Primack and T. E. Lovejoy, eds. Ecology, conservation and management of South-East Asian rainforests). New Haven, CN: Yale University Press.

Brown, K. S. Jr (1997) Diversity, disturbance, and sustainable use of Neotropical forests: insects as indicators for conservation monitoring. J. Insect Conserv. 1: 25-42. 
Bynum, D. Z. (1999) Assessment and monitoring of anthropogenic disturbance in Lore Lindu National Park, Central Sulawesi, Indonesia. Trop. Biodiv. 6: 43-57.

Chao, A., Ma, M.-C. and Yang, M. C. K. (1993) Stopping rules and estimation for recapture debugging with unequal failure rates. Biometrika 80: 193-201.

Coates, B., Bishop, K. D. and Gardner, D. (1997) A guide to the birds of Wallacea: Sulawesi, the Moluccas and Lesser Sunda Islands, Indonesia. Alderley, Queensland: Dove Publications.

Collins, N. M., Sayer, J. A. and Whitmore, T. C. (1991) The conservation atlas of tropical forests: Asia and the Pacific. London: Macmillan.

Colwell, R. K. (1997) EstimateS. Statistical estimation of species richness and shared species from samples. Version 5. User's Guide and application published at: http://viceroy.eeb. uconn.edu/estimates (accessed January 2002).

Colwell, R. K., Mao, C. X. and Chang, J. (2004) Interpolating, extrapolating, and comparing incidence-based species accumulation curves. Ecology 85: 2717-2727.

Cooper, D. S. and Francis, C. M. (1998) Nest predation in a Malaysian lowland rainforest. Biol. Conserv. 85: 199-202.

Dale, S., Mork, K., Solvang, R. and Plumptre, A.J. (1999) Edge effects on the understorey bird community in logged forest in Uganda. Conserv. Biol. 14: 265-276.

DeVries, P. J. (1987) The butterflies of Costa Rica and their natural history: Papilionidae, Pieridae, Nymphalidae. Princeton, NJ: Princeton University Press.

Driscoll, P. V. and Kikkawa, J. (1989) Bird species diversity of lowland tropical rainforests of New Guinea and northern Australia. Pp. 122-152 in M. L. Harmelin-Vivien and F. Bourlière, eds. Vertebrates in complex tropical systems. Berlin: Springer (Ecological studies no. 69).

Fermon, H., Waltert, M., Larsen, T. B., Dall'Asta, U. and Mühlenberg, M. (200o) Effects of forest management on diversity and abundance of fruit-feeding Nymphalid butterflies in southeastern Côte d'Ivoire. J. Insect Conserv. 4: 173-188.

Fermon, H., Waltert, M., Vane-Wright, R. I. and Mühlenberg, M. (2005) Forest use and vertical stratification in fruit-feeding butterflies of Sulawesi, Indonesia. Impacts for conservation. Biodiv. Conserv. 14: 333-350.

FWI/GWF (2002) The state of the forest: Indonesia. Bogor, Indonesia and Washington, DC: Forest Watch Indonesia and Global Forest Watch.

Greenberg, R. (1981) The abundance and seasonality of forest canopy birds on Barro Colorado Island, Panama. Biotropica 13: 241-251.

Hill, J. K., Hamer, K. C., Lace, L. A. and Banham, W. M. T. (1995) Effects of selective logging on tropical forest butterflies on Buru, Indonesia. J. Appl. Ecol. 32: 754-76o.

Johns, A. G. (1996) Bird population persistence in Sabahan logging concessions. Biol. Conserv. 75: 3-10.

Johns, A. G. (1997) Timber production and biodiversity conservation in tropical rain forests. Cambridge, U.K.: Cambridge University Press.

Karim-Dakog, A., Sharim-Senik, M., Zubaid, A. and Davison, G. W. H. (1997) Understorey avifauna of the UKM Forest Reserve, a fragmented and disturbed lowland rainforest. Malayan Nature J. 50: 337-346.

Karr, J. R. (1981). Surveying birds in the tropics. Pp. 548-553 in C. J. Ralph and J. M. Scott, eds. Estimating numbers of terrestrial birds. (Studies in Avian Biology no. 6). Caldwell, NJ: Blackburn Press.

Karr, J. R. (1982) Avian extinction on Barro Colorado island, Panama: a reassessment. Am. Nat. I19: 220-239.

Kessler, M., Kessler, P. J. A., Gradstein, S. R., Bach, K., Schmull, M. and Pitopang, R. (2005) Tree diversity in primary forests and different land use systems in Central Sulawesi, Indonesia. Biodiv. Conserv. 14: 547-560.

Lambert, F. (1992) The consequences of selective logging for Bornean lowland forest birds. Phil. Trans. R. Soc. Lond. Ser. B. 335: 443-457.

Laurance, W. F., Lovejoy, T. E., Vasconcelos, H. L., Bruna, E. M., Didham, R. K., Stouffer, P. C., Gascon, C., Bierregaard, R. O., Laurance, S. G. and Sampaio, E. (2002) Ecosystem decay of Amazonian forest fragments: a 22-year investigation. Conserv. Biol. 16: 630-640. 
Lens, L., van Dongen, S., Wilder, C. M., Brooks, T. M. and Mattysen, E. (1999) Fluctuating asymmetry increases with habitat disturbance in seven bird species of a fragmented afrotropical forest. Proc. R. Soc. Lond., Ser. B 266: 1241-1246.

Levey, D. J. (1988) Tropical wet forest treefall gaps and distributions of understorey birds and plants. Ecology 69: 1076-1089.

MacKinnon, K., Hatta, G., Halim, H. and Mangalik, A. (1997) The ecology of Kalimantan. Oxford: Oxford University Press.

Magurran, A. E. (1988) Ecological diversity and its measurement. Princeton, NJ: Princeton University Press.

Marsden, S. J. (1998) Changes in bird abundances following selective logging on Seram, Indonesia. Conserv. Biol. 12: 605-611.

Mason, D. (1996) Responses of Venezuelan understorey birds to selective logging, enrichment strips and vine cutting. Biotropica 29: 296-309.

Merker, S. and Ebert, J. (in press) Notes on understorey bird species composition along a gradient of human disturbance in Central Sulawesi, Indonesia. Kukila.

Monroe, B. L. and Sibley, C. G. (1993) A world checklist of birds. New Haven, CN: Yale University Press.

Murphy, D. D. (1989) Conservation and confusion: wrong species, wrong scale, wrong conclusions. Conserv. Biol. 3: 82-84.

Myers, N., Mittermeier, R. A., Mittermeier, C. G., da Fonseca, G. A. B. and Kent, J. (2000) Biodiversity hotspots for conservation priority. Nature $403853-858$.

Nichols, J. D. and Conroy, M. J. (1996) Estimation of species richness. Pp. 226-234 in D. E. Wilson, F. R. Cole, J. D. Nichols, R. Rudran and M. Foster, eds. Measuring and monitoring biological diversity. Washington, DC: Smithsonian Institution Press.

Nur Mallo, F. and Ma'dika, B. P. (1999) A checklist of the birds of Lore Lindu National Park, Central Sulawesi, Indonesia. Palu, Sulawesi Tengah: Balai Taman Nasional Lore Lindu and The Nature Conservancy.

O'Brien, T. G. and Kinnaird, M. F. (1996) Changing populations of birds and mammals in North Sulawesi. Oryx 30: 150-156.

O'Brien, T. G. and Kinnaird, M. F. (2000) Differential vulnerability of large birds and mammals to hunting in North Sulawesi, Indonesia, and the outlook for the future. Pp. 199-213 in J. G. Robinson and E. L. Bennett, eds. Hunting for sustainability in tropical forest. New York: Columbia University Press.

Pangau-Adam, M. Z. (2003) Avian nest predation in forest margin areas in Lore Lindu National Park, Central Sulawesi, Indonesia. PhD thesis, Georg August University of Göttingen, published at http://webdoc.sub.gwdg.de/diss/2003/pangau/index.html (accessed March 2004).

Pearson, D. L. (1971) Vertical stratification of birds in a tropical dry forest. Condor 73: 46-55.

Rosenbaum, B., O'Brien, T. G., Kinnaird, M. F. and Supriatna, J. (1998). Population densities of Sulawesi black macaques Macaca nigra on Bacan and Sulawesi, Indonesia: effects of habitat disturbance and hunting. Am. J. Primatol. 44: 89-106.

Schulze, C. H., Waltert, M., Kessler, P. J. A., Pitopang, R., Shahabuddin, Veddeler D., Mühlenberg, M., Gradstein, S. R., Leuschner, C., Steffan-Dewenter, I. and Tscharntke, T. (2004) Biodiversity indicator groups of tropical land-use systems: comparing plants, birds and insects. Ecol. Appl. 14: 1321-1333.

Statsoft (1995) Statistica 5.1. Volume I. Tulsa, OK: Statsoft.

Stattersfield, A. J., Crosby, N. J., Long, A. G. and Wege, D. C. (1998) Endemic bird areas of the world: priorities for bird conservation. Cambridge, U.K.: BirdLife International.

Terborgh, J. and Diamond, J. M. (1970) Niche overlap in feeding assemblages of New Guinea Birds. Wilson Bull. 82: 29-52.

Thiollay, J.-M. (1992) Influence of selective logging on bird species diversity in a Guianan rain forest. Conserv. Biol. 6: 47-63. 
Thiollay, J.-M. (1995) The role of traditional agroforests in the conservation of rain forest bird diversity in Sumatra. Conserv. Biol. 9: 335-353.

Thiollay, J.-M. and Rahman, Z. (2002) The raptor community of Central Sulawesi: habitat selection and conservation status. Biol. Conserv. 107: 111-122.

TNC/BTNLL (2002) Lore Lindu National Park. Draft Management Plan 2002-2027. Palu, Indonesia: Directorat Jenderal Perlindungan Hutan dan Konservasi Alam and The Nature Conservancy.

Waltert, M. (200oa) Diversity and structure of a bird community in a logged forest in south-east Côte d'Ivoire. PhD thesis. Georg August University Göttingen. Published at: http://webdoc. gwdg.de/diss/200o/waltert/

Waltert, M. (200ob) Forest management and the distribution of understorey birds in the Bossematié Forest, Eastern Ivory Coast. Ostrich 71: 295-299.

Waltert, M., Langkau, M., Maertens, M., Erasmi, S., Härtel, M., and Mühlenberg, M. (2004a). Predicting losses of lowland bird species from deforestation in Central Sulawesi. Pp. 327-338 in G. Gerold, E. Guhardja and M. Fremerey, eds. Land use, nature conservation and the stability of rainforest margins in Southeast Asia. Berlin: Springer.

Waltert, M., Mardiastuti, A. and Mühlenberg, M. (2004b) Effects of land use on bird species richness in Sulawesi, Indonesia. Conserv. Biol. 15: 1339-1346.

Watling, D. (1983) Ornithological notes from Sulawesi. Emu 83: 247-261.

White, C. M. N. and Bruce, M. D. (1986) The birds of Wallacea (Sulawesi, the Moluccas and Lesser Sunda islands, Indonesia). An annotated checklist. London: British Ornithologist's Union (BOU Check-List no. 7).

Wong, M. (1985) Understorey birds as indicators of regeneration in a patch of selectively logged west Malaysian rain forest. Pp. 249-263 in A. W. Diamond and T. E. Lovejoy, eds. Conservation of tropical forest birds. Cambridge, U.K.: International Council for Bird Preservation (Technical Publication no. 4).

Wong, T. C. M., Sodhi, N. S. and Turner, I. M. (1998) Artificial nest and seed predation experiments in tropical lowland rainforest remnants of Singapore. Biol. Conserv. 85: 97-104.

Wood, B. and Gillman, M. P. (1998) The effects of disturbance on forest butterflies using two methods of sampling in Trinidad. Biodiv. Conserv. 7: 597-616.

MATTHIAS WALTERT ${ }^{1}$, MICHAEL MÜHLENBERG

Centre for Nature Conservation (Dept. I), Georg August University Göttingen, Von-SieboldStrasse 2, 37075 Göttingen, Germany

\section{ANI MARDIASTUTI}

Department of Forest Resources Conservation, Bogor Agricultural University, P. O. Box 168, Bogor 160o1, Indonesia

${ }^{1}$ Author for correspondence; e-mail: mwalter@gwdg.de

Received 3 March 2004; revision accepted 19 February 2004. 